\title{
Real-Time PCR Assays to Detect and Distinguish the Rapid 'Ōhi'a Death Pathogens Ceratocystis lukuohia and C. huliohia
}

\author{
Wade P. Heller and Lisa M. Keith ${ }^{\dagger}$
}

First author: University of Hawai'i at Mānoa, College of Tropical Agriculture and Human Resources, Komohana Research and Extension Center, 875 Komohana St., Hilo 96720; and second author: USDA-ARS, Daniel K. Inouye U.S. Pacific Basin Agricultural Research Center, Tropical Plant Genetic Resources and Disease Research Unit, 64 Nowelo St., Hilo 96720.

Accepted for publication 6 June 2018.

\begin{abstract}
Ceratocystis lukuohia and C. huliohia are recently described fungal species that cause rapid 'ōhi'a death (ROD) of Metrosideros polymorpha, Hawaii's most abundant and ecologically important native species. Although the pathogens are now widespread on Hawai'i Island, a major effort is underway to study and manage affected forests, and particularly to prevent the disease from spreading to other islands in the State or throughout the Pacific. Rapid and accurate detection is critical. Molecular diagnostic real-time PCR protocols were developed to detect and
\end{abstract}

ABSTRACT

Metrosideros polymorpha ('ōhi'a lehua) is a broadleaf evergreen tree that is endemic to Hawai' $i$ and plays a critical role in native forests by providing habitat to many endemic and endangered flora and fauna (Friday and Herbert 2006; Sakai and Carpenter 1990; Warshauer and Jacobi 1982). This keystone species is also of great importance to local watersheds. 'Ōhi'a trees provide for recharge of groundwater, which is tapped for human use and has conservative water use compared with other nonnative species (Cavaleri et al. 2014; Kagawa et al. 2009). The species also has deep ties to the culture of the Hawaiian people (Friday and Herbert 2006). Two distinct species of the Ceratocystis fimbriata complex have been identified and described as emerging exotic pathogens of 'ōhi'a (Barnes et al. 2018; Keith et al. 2015). The combined mortality associated with both pathogens is colloquially known as rapid 'ōi'a death (ROD), which describes the rapid progression of canopy browning (often over days to weeks) once symptoms first appear. Unusual 'ōhi'a mortality consistent with ROD was first reported in the Puna district of Hawai'i Island during 2009 to 2010; however, it was not until 2014 that lab testing confirmed one of the two pathogens (at that time called C. fimbriata) was killing trees (Keith et al. 2015). Subsequently, a second species of Ceratocystis was also isolated from dead 'ōhi'a and pathogenicity

${ }^{\dagger}$ Corresponding author: L. M. Keith; E-mail: lisa.keith@ars.usda.gov

Funding: This research was supported by generous contributions from the Hau'oli Mau Loa Foundation, Gordon and Betty Moore Foundation, Hawaii Tourism Authority, and the Hawai'i Invasive Species Council.

This article is in the public domain and not copyrightable. It may be freely reprinted with customary crediting of the source. The American Phytopathological Society, 2018.

Mention of trademark, proprietary product, or vendor does not constitute a guarantee or warranty of the product by the U.S. Department of Agriculture and does not imply its approval to the exclusion of other products or vendors that also may be suitable.

*The $\boldsymbol{e}$-Xtra logo stands for "electronic extra" and indicates that two supplementary tables are published online.

(c) 2018 The American Phytopathological Society distinguish the two pathogens, suitable for detection of fungal DNA from extracts of wood, soil, and insect frass. The assays detect as few as 2 to 4 or 16 spores of $C$. huliohia or C. lukuohia, respectively. These assays are valuable tools for monitoring disease spread and offer a significant advantage over culture-based methods for diagnostics, requiring $<1$ day to arrive at definitive results.

Additional keywords: Ceratocystis fimbriata, qPCR.

was confirmed by laboratory inoculations (Barnes et al. 2018). As of 2018, the two species are widespread on Hawai'i Island, but have not been found on other islands in the State, nor anywhere else in the world.

Aerial surveys conducted in 2016 and 2017, combined with onthe-ground sampling, estimate ROD-affected 'ōhi'a forests spanned 48,000 and 75,000 acres, respectively (of $\sim 850,000$ acres statewide), an increase of approximately $50 \%$ between the two surveys. Mortenson et al. (2016) reported average annual 'ohi'a mortality rates of $28 \%$ within forest monitoring plots in stands where ROD has been confirmed. Some of those stands had up to $50 \%$ annual mortality. The potential spread of this devastating disease along the Hawaiian archipelago is a major threat to the state's forest ecosystems, and as such, an interisland quarantine of 'ohi'a material is in place for Hawai'i Island (Hawaii Administrative Rules 2016). Regular surveys for new outbreaks are being conducted on all islands as part of the early detection, rapid response effort, of which rapid diagnostic testing is a critical component.

Current research underway has found evidence, yet unpublished, that $C$. lukuohia causes a systemic vascular wilt disease that can result in complete wilt of ohia crowns within one month of artificial inoculation (J. Juzwik, personal communication). In contrast, artificial inoculation of ohia stems with $C$. huliohia results in formation of bark cankers and deep xylem staining within 6 weeks. Although the outward disease symptoms of either pathogen (rapid browning of canopy over a period of days to weeks) often appear similar, the mode and extent of sapwood colonization by the two fungal pathogens are different. In particular, C. huliohia, the less aggressive of the two pathogens, has been observed to sometimes cause browning of individual branch forks above coalesced $C$. huliohia cankers, in naturally infected, mature trees. Both C. lukuohia and C. huliohia have been previously referred to as $C$. fimbriata; however, their host ranges, mating compatibilities, and other phylogenetic considerations all support their designations as species novae (Barnes et al. 2018). Here we describe a molecular diagnostic tool for definitively identifying and distinguishing the DNA of the two pathogens present in infected wood, soil, and insect material.

Prior to the development of diagnostic molecular markers to distinguish $C$. lukuohia and C. huliohia, culture-based methods 
(i.e., carrot-baiting [Moller and DeVay 1968]) were used to detect the presence of Ceratocystis spp. from infected 'ōhi'a wood. Approximately 1 month is required to complete carrot-baiting, purify isolates, extract, and amplify DNA in order to definitively identify one or both pathogens in wood of suspect samples. Additionally, culture-based testing for Ceratocystis is limited by the susceptibility of cultures to microbial contamination, the favorability of spore germination conditions (e.g., moisture content of wood material and age of spores), and the ability to visually discern fungal structures (mycelium or perithecia) of Ceratocystis from those of other ascomycetes. For these reasons, we sought to develop a molecular diagnostic tool for rapid, direct detection which provides species-level identification of C. lukuohia and C. huliohia from DNA isolated directly from infected wood of 'ohi'a-infested soil and Ceratocystis spp. in ambrosia beetle frass.

\section{MATERIALS AND METHODS}

Fungal isolates. Sixty-two C. lukuohia and nine C. huliohia isolates were obtained from 'ōhi'a samples collected in the Puna, Hilo, and Kona districts of Hawai'i Island in 2014 and 2015. To obtain fungal isolates, 'ōhi'a trees exhibiting characteristic ROD symptoms were sampled and trunk cross sections (i.e., cookies) or wood chips with dark discolored sapwood were collected. Ceratocystis was isolated according to the carrot-baiting method of Moller and DeVay (1968), and single perithecia were transferred to culture plates $\left(10 \% \mathrm{~V} 8\right.$ agar) and maintained at $25^{\circ} \mathrm{C}$. Singleperithecia isolates were deposited into the USDA-ARS D. K. Inouye U.S. Pacific Basin Agricultural Research Center (PBARC) collection, then screened for ITS haplotypes belonging to either C. lukuohia or C. huliohia. C. fimbriata recovered from sweet potato (Ipomoea batatas) from a local supermarket was included in the study. Additionally, extracted DNA was obtained from the Centraalbureau voor Schimmelcultures, CBS Fungal Biodiversity Centre (Utrecht, NL) for accessions of Ceratocystis spp. isolates from Hawai'i: (i) CBS114719, a Ceratocystis sp. isolated from Syngonium podophyllum (Thorpe et al. 2005), and (ii) CBS114720 and CBS115164, accessions of C. uchidae isolated from Colocasia esculenta ( $\mathrm{Li}$ et al. 2017; Uchida and Aragaki 1979). GenBank accession numbers of sequenced PCR products are shown in Table 1.

DNA sequence analysis. Primers and PCR conditions for amplification of genomic loci were as previously described; amplicons included ribosomal DNA ITS (White et al. 1990), cerato-platanin $(C P)$ (Luchi et al. 2013), beta-tubulin (Glass and Donaldson 1995), glyceraldehyde-3-phosphate dehydrogenase $(G A P D H)$ (Templeton et al. 1992), actin (Carbone and Kohn 1999), and translation elongation factor-1 alpha (TEF-1 $\alpha$ ) (Harrington 2009). GoTaq DNA polymerase (Promega, Madison, WI) was used for all amplifications. PCR products were cleaned up using ExoSAP-IT (ThermoFisher, Waltham, MA) and submitted for bulk Sanger DNA sequencing (Eurofins Genomics, Louisville, KY). DNA sequences were primer-trimmed using Sequencher version 5.4.6 (GeneCodes Corp., Ann Arbor, MI), alignments were prepared using MEGA6 (Tamura et al. 2013) and uploaded to TreeBASE as accession 21414.

Real-time PCR assay design. Once suitable polymorphic priming sites were identified within the cerato-platanin gene, primers that discriminate between $C$. lukuohia, C. huliohia, and C. fimbriata were designed (Fig. 1A). Each primer pair is specific to one of the three Ceratocystis species present in Hawai'i, and the specificity is determined primarily by polymorphic residues at the $3^{\prime}$-end of each primer. A universal FAM-labeled, TaqMan MGB (minor groove binding) probe (ThermoFisher) was used for detection of all three Ceratocystis amplicons. The sequence of all three species-specific Ceratocystis amplicons were verified by bulk DNA sequencing of the PCR products.

Additionally, as a positive control for extraction and amplification from 'ôhi'a, a primer pair and probe were developed for $\mathrm{MeNu} 47$, a putative glycoside hydrolase identified as a conserved low-copy nuclear gene within the family Myrtaceae (Pillon et al. 2014). The MeNu47 probe is VIC-labeled for the assays to allow for multiplexing of the individual Ceratocystis species targets with the MeNu47 internal positive control. Primer and probe sequences are shown in Table 2.

Collection, storage, and handling of suspect disease specimens. Between October 2015 through April 2017, 1,645 independent samples were collected directly or submitted for testing through our partnerships with the U.S. Forest Service, University of Hawai'i, Hawai'i Department of Agriculture, Big Island Invasive Species Committee, National Park Service, as well as individual land managers and private property owners. Samples types included wood discs (= "cookies"), hatchet chips, sawdust, drill shavings, soil (usually from the base of suspect trees), and ambrosia beetle frass (boring dust caught in bark in the lower portion of the tree bole). Sanitation by $10 \%$ chlorine bleach or flame sterilization was used to clean tools between samples. Samples were submitted in sealed plastic bags and stored at room temperature. Most samples were processed within $48 \mathrm{~h}$ of collection. Some samples submitted were composite sawdust collections from groups of logs being tested as a lot. In addition to molecular testing (described below), incoming suspect disease samples were also subjected to culture-based screening for Ceratocystis using carrotbaiting methods (Moller and DeVay 1968), and the species identity of recovered isolates was confirmed using the qPCR assays we present here.

DNA testing suspect wood, soil and insect frass samples for Ceratocystis. Unless supplied as sawdust or drill shavings, wood samples were broken down using a flame sterilized 1/4 inch drill bit. Wood shavings ( $100 \mathrm{mg}$ ) were transferred to $2.0-\mathrm{ml}$ screwtop grinding tubes filled with $6,3.0-\mathrm{mm}$ zirconium grinding beads (OPS Diagnostics, Lebanon, NJ). Wood DNA extractions were performed using a commercial plant DNA extraction kit (NucleoSpin Plant-II DNA kit, Machery-Nagel, Bethlehem, PA), following the manufacturer's recommended protocol with the following modifications: (i) double volumes of buffers PL2 and PL3 (600 and $150 \mu \mathrm{l}$, respectively) were used to accommodate the dry starting material, and (ii) the wood shavings and extraction

TABLE 1. GenBank accession numbers for DNA sequences obtained from Ceratocystis species isolates used in the development of the real-time PCR assays

\begin{tabular}{|c|c|c|c|c|c|c|c|c|c|}
\hline Classification & Host & Location & Isolate IDs & ITS & $C P$ & $\beta$-tubulin & $T E F-1 \alpha$ & Actin & $G A P D H$ \\
\hline C. lukuohia & M. polymorpha & Hawai'i, USA & $\begin{array}{l}\text { P14-1-1, P14-8, } \\
\text { P15-14, P15-18 } \\
\text { P15-6, P15-11 }\end{array}$ & $\begin{array}{l}\text { KP203957a } \\
\text { KU043251 }\end{array}$ & KU043257 & KU043263 & KU043289 & KU043245 & KU043272 \\
\hline C. huliohia & M. polymorpha & Hawai'i, USA & $\mathrm{P} 15-3, \mathrm{P} 15-59$ & KU043252 & KU043258 & KU043264 & KU043290 & KU043246 & KU043273 \\
\hline C. fimbriata & I. batatas & Hawai'i, USA & $\mathrm{P} 15-30, \mathrm{P} 15-31$ & KU043253 & KU043259 & KU043265 & KU043291 & KU043247 & KU043274 \\
\hline Ceratocystis sp. & S. podophyllum & Hawai'i, USA & CBS114719 & KU043248 & KU043254 & KU043260 & KU043286 & KU043242 & KU043269 \\
\hline C. uchidae & Colocasia esculenta & Hawai'i, USA & CBS114720 & KU043249 & KU043255 & KU043261 & KU043287 & KU043243 & KU043270 \\
\hline C. uchidae & Colocasia esculenta & Hawai'i, USA & CBS115164 & KU043250 & KU043256 & KU043262 & KU043288 & KU043244 & KU043271 \\
\hline
\end{tabular}

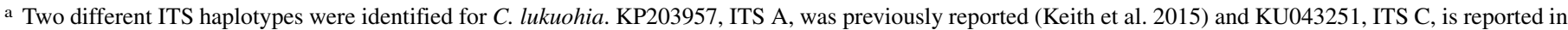
this study. Sequences for other loci of all C. lukuohia isolates were identical, regardless of ITS haplotype. 
buffer were homogenized $2 \times 60 \mathrm{~s}$ in a tissue homogenizer (FastPrep-24, MP Biomedicals, Solon, OH) at the maximum speed (6.5), with a 10 -min incubation at $65^{\circ} \mathrm{C}$ between the two grinding intervals. Clarified crude lysate $(300 \mu \mathrm{l}$ only) was utilized for DNA binding and as such all other reagent volumes remained unchanged.

Ambrosia beetle boring dust (frass) was collected from the bark of insect-attacked 'ōhi'a trees and processed the same as wood shavings. For soil samples, DNA was extracted using a commercial kit designed for DNA in soil (PowerLyzer PowerSoil DNA Isolation Kit, MO Bio, Carlsbad, CA) according to the manufacturer's protocol, with the modification that samples were homogenized with the FastPrep-24, speed 6.5, for $1 \mathrm{~min}$.
Real-time PCR. High throughput (96- and 384-well capacity) instruments (StepOnePlus and QuantStudio5, ThermoFisher) were used to run qPCR reactions. The $10-\mu l$ total volume reactions contained $5 \mu \mathrm{l}$ of $2 \times$ reaction mix (SensiFAST Probes Hi-ROX, Bioline, Taunton, MA), 400 and $100 \mathrm{nM}$ final concentration of primers and probes, respectively, and $1 \mu$ of purified template DNA. Routine samples were processed with duplicate reactions for each of two multiplexes: C. lukuohia/MeNu47 and C. huliohia/MeNu47. Validation assays (template specificity, Fig. 1B and spore dilution series, Table 3) were run in quadruplicate. Cycling parameters: 2-min initial denaturation at $95^{\circ} \mathrm{C}$, followed by 40 cycles of $10 \mathrm{~s}$ at $95^{\circ} \mathrm{C}$ and $30 \mathrm{~s}$ at $60^{\circ} \mathrm{C}$. The delta Rn fluorescence thresholds were adjusted to 0.02 and 0.004 on the StepOnePlus and QuantStudio5
A
C. lukuohia
C. huliohia
C. fimbriata
C. Iukuohia
C. huliohia
C. fimbriata
C. Iukuohia
C. huliohia
C. fimbriata

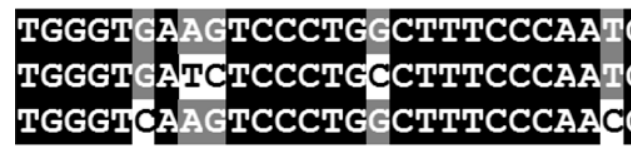

GCTGTGG IACTTGCTGGAAGGTCAC :
GCTGTGCIACTTGCTGGAAGGTCAC
GCTGTGCTACTTGCTGGAAGGTCAC

TaqMan Probe

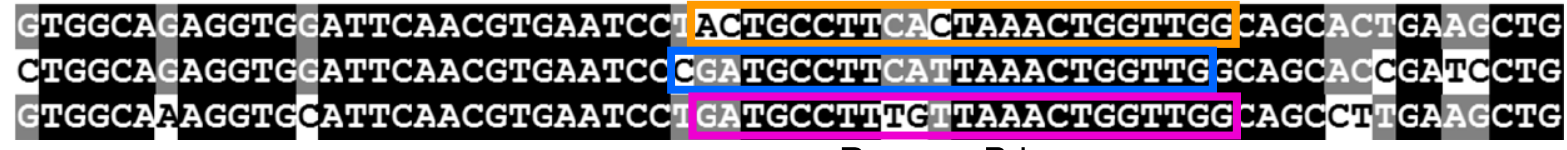

Reverse Primer
B

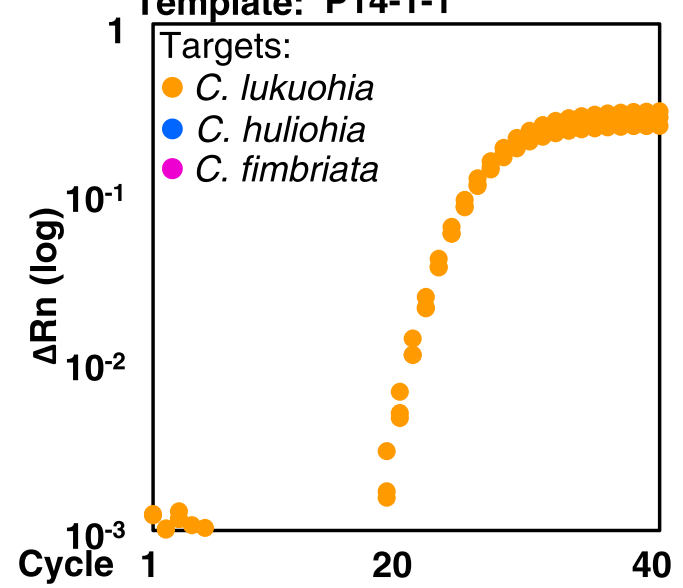

P15-59

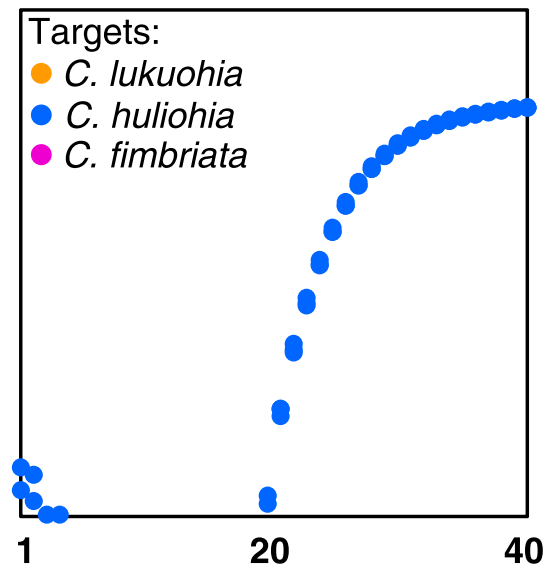

P15-31

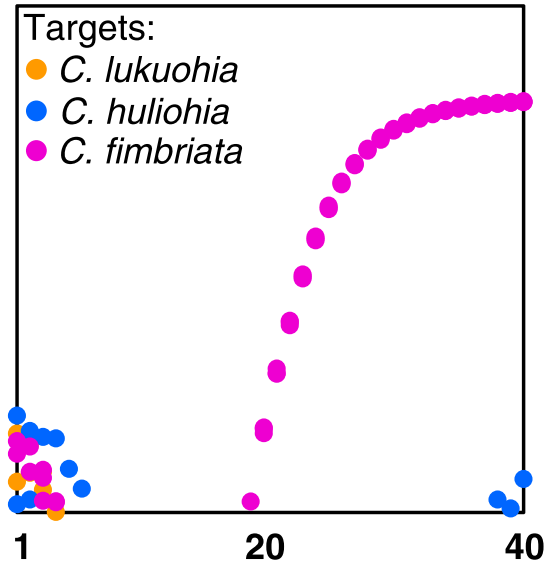

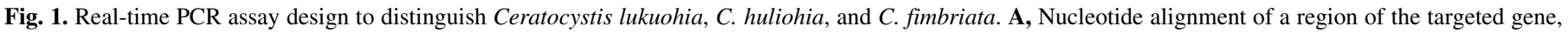

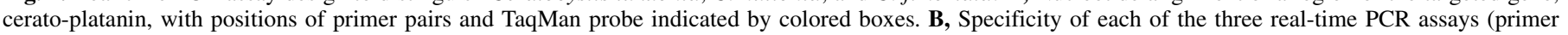

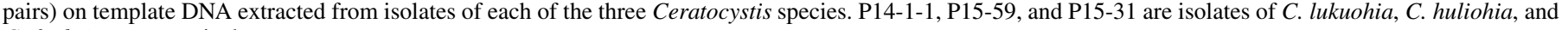
C. fimbriata, respectively.

TABLE 2. Primer and probe sequence used in the development of real-time PCR assays for Ceratocystis lukuohia and C. huliohia

\begin{tabular}{|c|c|c|c|c|}
\hline Target species & Oligo name & Sequence $\left(5^{\prime}\right.$ to $\left.3^{\prime}\right)$ & $\operatorname{Tm}\left({ }^{\circ} \mathrm{C}\right)$ & Product (bp) \\
\hline C. lukuohia & CP_For_A & TCCTGACATCGCCGGC & 58.7 & 147 \\
\hline C. lukuohia & CP_Rev_A & CCAACCAGTTTAGTGAAGGCAGT & 58.4 & 147 \\
\hline C. huliohia & CP_For_B & GGTGTTCCTGACATTGCCCAG & 61.3 & 151 \\
\hline C. huliohia & CP_Rev_B & CAACCAGTTTAATGAAGGCATCG & 59.5 & 151 \\
\hline C. fimbriata & CP_For_D & GGTATTCCTGACATCGCTGGA & 58.6 & 152 \\
\hline C. fimbriata & CP_Rev_D & CCAACCAGTTTAACAAAGGCATC & 58.6 & 152 \\
\hline Ceratocystis spp. & CP_Uni_Probe & FAM-TACTTGCTGGAAGGTCAC-MGB & 70.0 & $147-152$ \\
\hline Myrtaceae & $\mathrm{MeNu} 4 \overline{7}+20 \mathrm{For}$ & CTCCTATAAGGTAATCAACTCCTCATTG & 58.0 & 167 \\
\hline Myrtaceae & $\mathrm{MeNu} 47_{-}+186 \mathrm{R}$ & CAACGACTAGGCAATTTATGGAGAA & 59.8 & 167 \\
\hline Myrtaceae & MeNu47_Probe & VIC-CTTCTGATGTCAAAAGCAGA-MGB & 69.0 & 167 \\
\hline
\end{tabular}


instruments, respectively. $\mathrm{Ct}$ values of 16 to 40 were considered positive detections.

Real-time PCR assay validation. Specificity of primer pairs for detecting C. lukuohia, C. huliohia, and C. fimbriata was verified by testing fungal DNA extracts for the three species in reactions containing the three different real-time PCR mixtures. Aliquots $(1.0 \mu \mathrm{g})$ of fungal DNA extracted from pure cultures P14-1-1, P1559, and P15-31, corresponding to C. lukuohia, C. huliohia, and C. fimbriata, respectively, were tested in quadruplicate in all three reaction mixtures.

Standard curves were used to calculate the PCR efficiency of each Ceratocystis target. Fivefold serial dilutions of purified DNA from fungal cultures (P14-1-1, P15-59, and P15-31) were used as template DNA and all dilutions were tested for cross reactivity with the primers for all three species. DNA concentration was measured with a fluorimeter (Qubit, ThermoFisher). DNA input amount ranged from $1.28 \times 10^{-3}$ to $2.0 \times 10^{1} \mathrm{ng}$ into a $10-\mu \mathrm{l}$ reaction. Mean $\mathrm{Ct}$ values of quadruplicate reactions were plotted against the log of DNA concentration.

Assay sensitivity relative to spore concentration was determined by mixing a known concentration of endoconidia with $100 \mathrm{mg}$ of uninfected 'ōi'a wood shavings, extracting DNA from the spore suspension/wood mixture, and amplifying DNA using real-time PCR. Endoconidia were harvested by flooding pure cultures of C. lukuohia and C. huliohia (isolates P14-1-1 and P15-59, respectively) grown on $2 \%$ malt extract agar (BD Difco, ThermoFisher) followed by quick filtration (Miracloth, EMD Millipore, Billerica, MA). Spore density was measured using a hemocytometer. The spore concentration was then normalized and serially diluted (twofold) to generate a series with $1 \times 10^{2}$ to $5.12 \times 10^{4}$ spores per $100-\mu 1$ volume. After extraction, $1 \mu \mathrm{l}$ of DNA ( $1 \%$ of the total extract) was used per reaction; thus, the reactions contained template DNA from 1 to 512 spores each.

\section{RESULTS}

Phylogenetic relationships of Ceratocystis species known to occur in Hawaii were obtained based on sequences obtained for four gene regions (Fig. 2). For all genetic loci amplified except ceratoplatanin, nucleotide conservation of the amplicons was $>90 \%$.
Within the amplified region of cerato-platanin, C. lukuohia and C. huliohia share $387 / 443$ nucleotides ( $87.4 \%$ identity), and shared nucleotide identities of this gene relative to $C$. fimbriata are 94.6 and $86.0 \%$, respectively. Also within this region, suitably spaced polymorphic regions were available for primer design within the constraints of real-time PCR (Fig. 1A).

The qPCR primers for C. lukuohia do not cross react with template DNA from $C$. huliohia nor $C$. fimbriata; likewise, the primer combinations for $C$. huliohia and $C$. fimbriata are specific for their respective species and do not cross react with template DNA from the other two species (Fig. 1B). Cross reactivity of the Ceratocystis isolate recovered from $S$. podophyllum (CBS114719) does occur with the C. lukuohia real-time PCR assay, as do the two Colocasia esculenta isolates with the C. huliohia assay; however, the pathogens infecting $S$. podophyllum and Colocasia esculenta have never been found on 'ōhi'a. Additionally, isolates of Ophiostoma sp. and Leptographium bistatum, other closely related ascomycetes isolated from 'ōhi'a and Eucalyptus grandis, were tested using the C. lukuohia or C. huliohia qPCR assays and did not cross react.

To assess the efficiency of each assay, standard curves of serially diluted template DNA for each species were prepared (Fig. 3). Calculated PCR efficiency of 88.76, 93.21, and 91.72\% were obtained for C. lukuohia, C. huliohia, and C. fimbriata, respectively, with DNA concentrations from $0.128 \mathrm{pg} / \mu \mathrm{l}$ to $2.0 \mathrm{ng} / \mu \mathrm{l}$.

Assay sensitivity was measured by testing coextracts fungal and wood DNA from enumerated spore suspensions mixed with the standard mass of wood tissue used in routine extractions. C. lukuohia was detected in $4 / 4$ reactions with 16 or greater genomic copies per reaction, and C. huliohia was detected in $2 / 4$ reactions with 2 genomic copies and $4 / 4$ reactions with 4 or greater genomic copies per reaction (Table 3 ).

C. lukuohia and C. huliohia were detected in DNA extracts prepared from suspect samples of wood, soil, and frass samples (Table 4). Of 616 'ōhi'a wood samples, 21.1 and $12.3 \%$ tested positive for C. lukuohia and C. huliohia, respectively, while $2.4 \%$ were positive for both species. Ten of the eighteen samples testing positive for both species were composite samples from multiple logs; however, the remainder were from individual trees actually cocolonized by both pathogens.

TABLE 3. Limits of detection for Ceratocystis lukuohia and C. huliohia using developed real-time PCR assays based on serial dilutions of fungus spores mixed into set volume of pathogen-free ohia wood shavings

\begin{tabular}{|c|c|c|c|c|c|c|}
\hline Multiplex & $\begin{array}{l}\text { Genomic copy } \\
\text { number }^{\mathrm{a}}\end{array}$ & $\begin{array}{l}\text { Number of positive } \\
\text { reactions }^{b}\end{array}$ & $\begin{array}{c}\text { Cycle threshold }(\mathrm{Ct}) \\
\text { Ceratocystis }\end{array}$ & $\begin{array}{c}\text { Standard deviation (SD) } \\
\text { Ceratocystis }\end{array}$ & $\begin{array}{c}\mathrm{Ct} \\
\mathrm{MeNu} 47\end{array}$ & $\begin{array}{c}\mathrm{SD} \\
\mathrm{MeNu} 47\end{array}$ \\
\hline C. lukuohia/MeNu47 & 0 & $0 / 4$ & n.d. ${ }^{c}$ & n.d. & 19.2 & 0.19 \\
\hline C. lukuohia/MeNu47 & 1 & $0 / 4$ & n.d. & n.d. & 19.9 & 0.09 \\
\hline C. lukuohia/MeNu47 & 2 & $0 / 4$ & n.d. & n.d. & 19.7 & 0.09 \\
\hline C. lukuohia/MeNu47 & 4 & $0 / 4$ & n.d. & n.d. & 19.0 & 0.09 \\
\hline C. lukuohia/MeNu47 & 8 & $0 / 4$ & n.d. & n.d. & 19.0 & 0.12 \\
\hline C. lukuohia/MeNu47 & 16 & $4 / 4$ & 38.7 & 1.11 & 19.6 & 0.16 \\
\hline C. lukuohia/MeNu47 & 32 & $4 / 4$ & 36.6 & 0.71 & 19.1 & 0.11 \\
\hline C. lukuohia/MeNu47 & 64 & $4 / 4$ & 34.2 & 2.55 & 19.0 & 0.14 \\
\hline C. lukuohia/MeNu47 & 128 & $4 / 4$ & 31.8 & 2.01 & 19.8 & 0.03 \\
\hline C. lukuohia/MeNu47 & 256 & $4 / 4$ & 26.2 & 0.37 & 19.0 & 0.19 \\
\hline C. lukuohia/MeNu47 & 512 & $4 / 4$ & 25.4 & 0.35 & 19.7 & 0.07 \\
\hline C. huliohia/MeNu47 & 0 & $0 / 4$ & n.d. & n.d. & 19.5 & 0.18 \\
\hline C. huliohia/MeNu47 & 1 & $0 / 4$ & n.d. & n.d. & 19.6 & 0.15 \\
\hline C. huliohia/MeNu47 & 2 & $2 / 4$ & 37.0 & 0.37 & 18.9 & 0.06 \\
\hline C. huliohia/MeNu47 & 4 & $4 / 4$ & 35.5 & 1.60 & 19.6 & 0.10 \\
\hline C. huliohia/MeNu47 & 8 & $4 / 4$ & 31.1 & 0.62 & 19.5 & 0.13 \\
\hline C. huliohia/MeNu47 & 16 & $4 / 4$ & 30.7 & 0.34 & 19.8 & 0.12 \\
\hline C. huliohia/MeNu47 & 32 & $4 / 4$ & 28.4 & 0.24 & 19.1 & 0.19 \\
\hline C. huliohia/MeNu47 & 64 & $4 / 4$ & 27.9 & 0.33 & 19.3 & 0.22 \\
\hline C. huliohia/MeNu47 & 128 & $4 / 4$ & 26.9 & 0.11 & 19.7 & 0.14 \\
\hline C. huliohia/MeNu47 & 256 & $4 / 4$ & 25.9 & 0.06 & 19.1 & 0.15 \\
\hline C. huliohia/MeNu47 & 512 & $4 / 4$ & 25.4 & 0.37 & 20.0 & 0.08 \\
\hline
\end{tabular}

a Calculated genomic copy number of template DNA per qPCR reaction, over a twofold dilution series using an enumerated spore suspension.

b Number of replicate reactions testing positive $(n=4)$.

c n.d., not detected. 
Of 59 total insect frass samples collected from symptomatic 'ōhi'a trees, 34.8 and $7.4 \%$ tested positive for C. lukuohia and C. huliohia, respectively. Soil had the lowest rate of Ceratocystis detection; only 3 of 110 soil samples tested positive for C. lukuohia. All of the soil detections were from the same collection, in which soil at the base of 24 known C. lukuohia-positive trees was targeted for collection. This ratio $(3 / 24=12.5 \%)$ represents our rate of Ceratocystis detection from soil collected in a forest stand displaying ROD symptomology. The remainder of the soil tested were considered to have low likelihood of detection since many samples were from nonhosts and/or nurseries.

Considerable variation was observed in the ability to culture C. lukuohia and C. huliohia from qPCR positive wood samples. Two major classes of wood samples were tested: trees that were freshly killed, and trees that had been harvested as logs and dried for 1 to 3 years. In wood samples tested from fresh mortality, such as those in Supplementary Table S1, 4/4 (100\%) of the C. huliohia DNA-positive samples tested positive by the culture-based method, and 2/4 (50\%) C. lukuohia DNA-positive samples were culture positives. On the other hand, the 184 HDOA samples in Supplementary Table S2 (individual or composite log samples tested for interisland shipment permits) were harvested 1 to 3 years prior to sampling/testing and had a much lower success rate of culturing compared with qPCR detections, only $6 / 66,<10 \%$.

\section{DISCUSSION}

Real-time PCR methods for the detection of C. lukuohia and C. huliohia were developed, tested and compared with traditional methods based on carrot baiting, PCR and sequencing. The molecular diagnostic assays we developed are capable of detecting as low as 16 spores within 100-mg wood sample for C. lukuohia and two to four spores for C. huliohia (Table 3). The molecular assays for C. lukuohia and C. huliohia offer a more consistent and robust testing method for presence of the pathogens than culture-based methods, especially on recalcitrant wood samples such as those derived from dry logs. Whereas qPCRpositive samples from freshly killed trees generally have a high rate of culture success $(>50 \%)$, under $10 \%$ (6 of 66 ) of samples from harvested logs yielded cultures after drying for 1 to 3 years. While part of this reduction in culture success may be directly attributed to reduced viability of spores over time, the carrot discs were also observed to desiccate in the sawdust from the older samples, which may cause them to be unfavorable for spore germination.

Based on the available genomic datasets, the gene for ceratoplatanin $(C P)$ was selected as the target region for the detection assays because of the high level of sequence polymorphism between the Ceratocystis spp. present in Hawai' $i$. In contrast, other real-time PCR detection assays for the detection of Ceratocystis spp. have targeted the rDNA ITS regions (Lamarche et al. 2015; Luchi et al. 2013; Pilotti et al. 2012; Wu et al. 2011; Yang and Juzwik 2017). One assay for the detection of $C$. platani is also based on a $C P$ target (Luchi et al. 2013). In consideration of assay development for $C$. lukuohia, the presence of two different ITS haplotypes within this species (Table 1) precluded the use of that locus for detection, thus $C P$ was used instead.

Although the exact role of $\mathrm{CP}$ proteins in pathogenesis remains unknown, the $C$. platani $\mathrm{CP}$ protein has been found to elicit phytoalexin synthesis in both host (Platanus spp.) and nonhost plants and binds oligosaccharides (de Oliveira et al. 2011; Pazzagli et al. 1999; Scala et al. 2004). The role of CP in the interaction between 'ōhi'a and Ceratocystis spp. has yet to be investigated.

Based on sexual compatibility assays and the analysis of microsatellite loci, both $C$. lukuohia and $C$. huliohia are thought to be recent, single introductions into Hawai'i (Barnes et al. 2018), yet it is unknown where they arrived from or how they were transported. A likely possibility is that they were disseminated on an alternate host(s) through the nursery trade; indeed, Ceratocystis sp. has been detected on S. podophyllum in Hilo nurseries. Syngonium podophyllum isolates collected from two different nurseries in 2016 cross reacted with the $C$. lukuohia detection assay (data not shown); however, the rDNA ITS sequences of these isolates were identical to the original 1979 S. podophyllum isolate (Uchida and Aragaki 1979), and different from C. lukuohia. Cross-host pathogenicity testing and mating studies have confirmed that the S. podophyllum pathogen is a distinct species from C. lukuohia, and also that C. uchidae, the Colocasia esculenta pathogen, is distinct from C. huliohia (Barnes et al. 2018). However, the cross reactivity of the C. lukuohia assay to detect Ceratocystis sp. on S. podophyllum, and the $C$. huliohia assay to detect $C$. uchidae on Colocasia esculenta can be used as diagnostic tools to screen plant material for the pathogens.

Our molecular assays for C. lukuohia and C. huliohia are powerful tools for monitoring and managing ROD. Our assay is already being used in research on the dispersal mechanisms of the
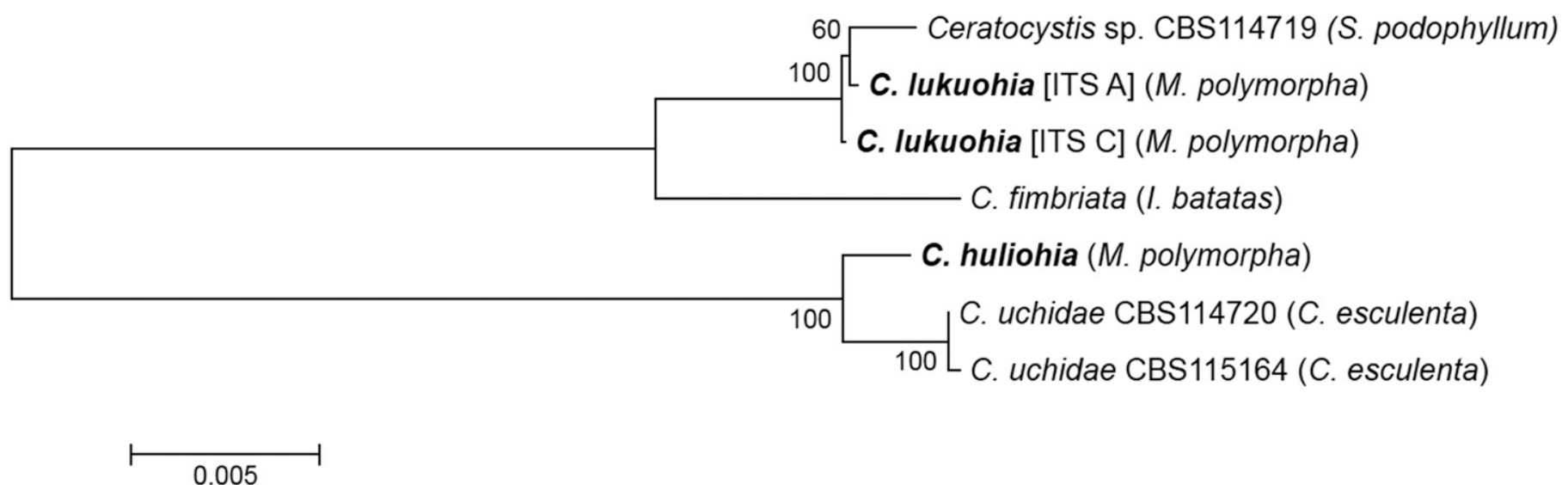

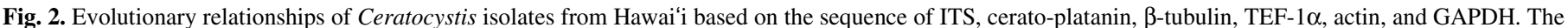

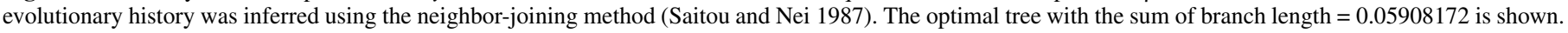

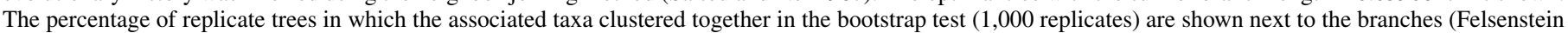

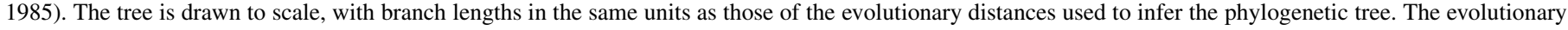

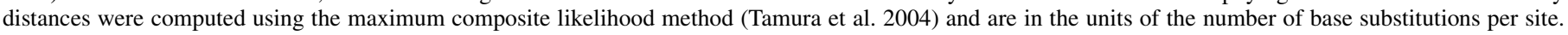

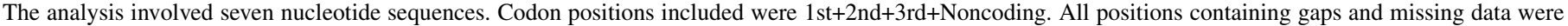
eliminated. There were a total of 3,511 positions in the final dataset. Evolutionary analyses were conducted in MEGA6 (Tamura et al. 2013). 
two ROD pathogens. In particular, the qPCR assay has already proven useful in the investigation of the role of wind-blown ambrosia beetle frass in transmission of the pathogens. Our assay is used for screening of C. lukuohia and C. huliohia on interisland shipments of 'ohi'a commodities originating on Hawai'i Island. Additionally, a state-wide screen of nurseries is planned, in an effort

A
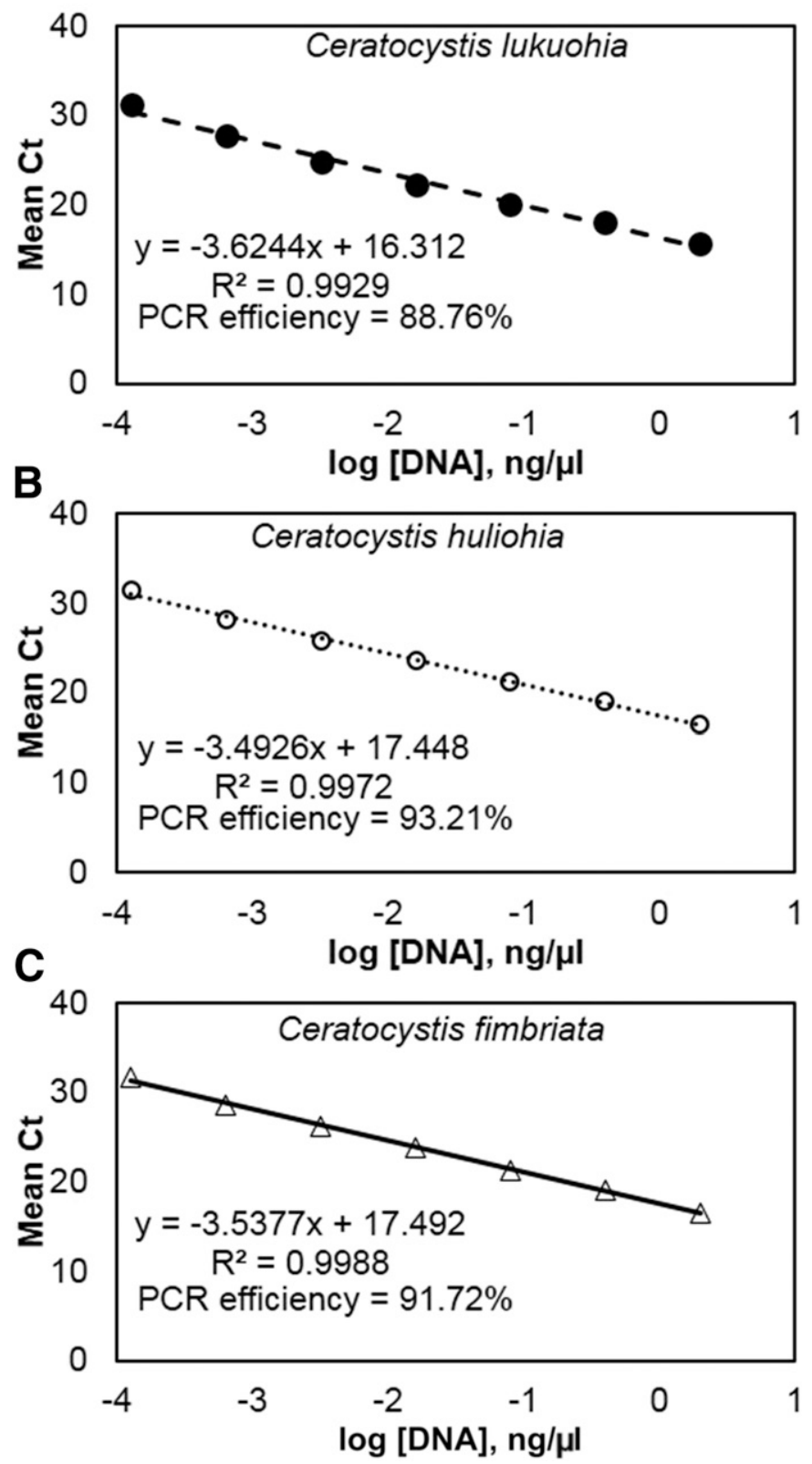

Fig. 3. Standard curves generated using genomic DNA from pure cultures of A, Ceratocystis lukuohia, B, C. huliohia, and C, C. fimbriata. Fivefold serial dilutions of DNA concentrations from $2.0 \mathrm{ng} / \mu \mathrm{l}$ to $0.128 \mathrm{pg} / \mu \mathrm{l}$ were used. Regression analysis was used to calculate $R^{2}$ values and PCR efficiency.

TABLE 4. Frequencies of Ceratocystis lukuohia and C. huliohia detected by real-time assays in samples from different substrates collected by various cooperators at multiple sites on Hawai'i Island between October 2015 and April 2017

\begin{tabular}{lccccc}
\hline & Samples & \multicolumn{4}{c}{ Number of samples with } \\
\cline { 3 - 6 } $\begin{array}{l}\text { Substrate } \\
\text { assayed } \\
\text { assayed }\end{array}$ & (number) & C. lukuohia & C. huliohia & $\begin{array}{c}\text { Both } \\
\text { fungi }\end{array}$ & $\begin{array}{c}\text { Neither } \\
\text { fungus }\end{array}$ \\
\hline Ohia wood & 616 & 92 & 63 & 18 & 443 \\
Insect frass & 59 & 18 & 7 & 0 & 34 \\
Soil & 57 & 3 & 0 & 0 & 54 \\
\hline
\end{tabular}

to characterize the genetic diversity of Ceratocystis spp. present in Hawai' $i$ and to prevent conditions allowing existing or newly introduced strains or species to sexually recombine. The availability of rapid detection assays enhances biosecurity by enabling preinvasion screening, and dramatically increases the potential for eradication of incipient introductions if these pathogens are accidentally introduced to other Hawaiian or Pacific Islands.

\section{ACKNOWLEDGMENTS}

We thank L. Sugiyama and B. Luiz for invaluable technical assistance.

\section{LITERATURE CITED}

Barnes, I., Fourie, A., Wingfield, M. J., Harrington, T. C., McNew, D. L., Sugiyama, L. S., Luiz, B. C., Heller, W. P., and Keith, L. M. 2018. New Ceratocystis species associated with rapid death of Metrosideros polymorpha in Hawai' $\mathrm{i}$. Persoonia 40:154-181.

Carbone, I., and Kohn, L. M. 1999. A method for designing primer sets for speciation studies in filamentous ascomycetes. Mycologia 91:553556.

Cavaleri, M. A., Ostertag, R., Cordell, S., and Sack, L. 2014. Native trees show conservative water use relative to invasive trees: Results from a removal experiment in a Hawaiian wet forest. Conserv. Physiol. 2:cou016.

de Oliveira, A. L., Gallo, M., Pazzagli, L., Benedetti, C. E., Cappugi, G., Scala, A., Pantera, B., Spisni, A., Pertinhez, T. A., and Cicero, D. O. 2011. The structure of the elicitor cerato-platanin (CP), the first member of the CP fungal protein family, reveals a double $\psi \beta$-barrel fold and carbohydrate binding. J. Biol. Chem. 286:17560-17568.

Felsenstein, J. 1985. Confidence limits on phylogenies: An approach using the bootstrap. Evolution 39:783-791.

Friday, J. B., and Herbert, D. A. 2006. Metrosideros polymorpha ('ōhi 'a), ver. 3.2. In: Species Profiles for Pacific Island Agroforestry. C. R. Elevitch, ed. Permanent Agricultural Resources (PAR), Hōlualoa, Hawai' ${ }^{i}$. http://agroforestry.org/free-publications/traditional-tree-profiles

Glass, N. L., and Donaldson, G. C. 1995. Development of primer sets designed for use with the PCR to amplify conserved genes from filamentous ascomycetes. Appl. Environ. Microbiol. 61:1323-1330.

Harrington, T. C. 2009. The genus Ceratocystis. Where does the oak wilt fungus fit? Pages 21-35 in: Proceedings of the 2nd National Oak Wilt Symposium. D. N. Appel and R. F. Billings, eds. Texas Forest Service Publication.

Hawaii Administrative Rules. 2016. Quarantine restrictions on ohia and soil from rapid ohia death infested areas. Amendment \$4-72-13.

Kagawa, A., Sack, L., Duarte, K., and James, S. 2009. Hawaiian native forest conserves water relative to timber plantation: Species and stand traits influence water use. Ecol. Appl. 19:1429-1443.

Keith, L. M., Hughes, R. F., Sugiyama, L. S., Heller, W. P., Bushe, B. C., and Friday, J. B. 2015. First report of Ceratocystis wilt on 'ōhi'a (Metrosideros polymorpha). Plant Dis. 99:1276.

Lamarche, J., Potvin, A., Pelletier, G., Stewart, D., Feau, N., Alayon, D. I. O., Dale, A. L., Coelho, A., Uzunovic, A., Bilodeau, G. J., Brière, S. C., Hamelin, R. C., and Tanguay, P. 2015. Molecular detection of 10 of the most unwanted alien forest pathogens in Canada using real-time PCR. PLoS One 10:e 0134265 .

Li, Q., Harrington, T. C., McNew, D., and Li, J. 2017. Ceratocystis uchidae, a new species on Araceae in Hawaii and Fiji. Mycoscience 58:398-412.

Luchi, N., Ghelardini, L., Belbahri, L., Quartier, M., and Santini, A. 2013. Rapid detection of Ceratocystis platani inoculum by quantitative real-time PCR assay. Appl. Environ. Microbiol. 79:5394-5404.

Moller, W. J., and DeVay, J. E. 1968. Carrot as a species-selective isolation medium for Ceratocystis fimbriata. Phytopathology 58:123-124.

Mortenson, L. A., Hughes, R. F., Friday, J. B., Keith, L. M., Barbosa, J. M., Friday, N. J., Liu, Z., and Sowards, T. G. 2016. Assessing spatial distribution, stand impacts and rate of Ceratocystis fimbriata induced 'ōhi'a (Metrosideros polymorpha) mortality in a tropical wet forest, Hawai'i Island, USA. For. Ecol. Manage. 377:83-92.

Pazzagli, L., Cappugi, G., Manao, G., Camici, G., Santini, A., and Scala, A. 1999. Purification, characterization, and amino acid sequence of ceratoplatanin, a new phytotoxic protein from Ceratocystis fimbriata f. sp. platani. J. Biol. Chem. 274:24959-24964.

Pillon, Y., Johansen, J., Sakishima, T., Chamala, S., Barbazuk, W. B., and Stacy, E. A. 2014. Primers for low-copy nuclear genes in Metrosideros and cross-amplification in Myrtaceae. Appl. Plant Sci. 2:1400049.

Pilotti, M., Lumia, V., Di Lernia, G., and Brunetti, A. 2012. Development of real-time PCR for in wood-detection of Ceratocystis platani, the agent of canker stain of Platanus spp. Eur. J. Plant Pathol. 134:61-79. 
Saitou, N., and Nei, M. 1987. The neighbor-joining method: A new method for reconstructing phylogenetic trees. Mol. Biol. Evol. 4:406-425.

Sakai, H., and Carpenter, J. 1990. The variety and nutritional value of foods consumed by Hawaiian crow nestlings, an endangered species. Condor 92 : 220-228.

Scala, A., Pazzagli, L., Comparini, C., Santini, A., Tegli, S., and Cappugi, G. 2004. Cerato-platanin, an early-produced protein by Ceratocystis fimbriata f. sp. platani, elicits phytoalexin synthesis in host and non-host plants. J. Plant Pathol. 86:23-29.

Tamura, K., Nei, M., and Kumar, S. 2004. Prospects for inferring very large phylogenies by using the neighbor-joining method. Proc. Natl. Acad. Sci. USA 101:11030-11035.

Tamura, K., Stecher, G., Peterson, D., Filipski, A., and Kumar, S. 2013. MEGA6: Molecular evolutionary genetics analysis version 6.0. Mol. Biol. Evol. 30:2725-2729.

Templeton, M. D., Rikkerink, E. H., Solon, S. L., and Crowhurst, R. N. 1992. Cloning and molecular characterization of the glyceraldehyde-3-phosphate dehydrogenase-encoding gene and cDNA from the plant pathogenic fungus Glomerella cingulata. Gene 122:225-230.
Thorpe, D. J., Harrington, T. C., and Uchida, J. Y. 2005. Pathogenicity, internal transcribed spacer-rDNA variation, and human dispersal of Ceratocystis fimbriata on the family Araceae. Phytopathology 95:316-323.

Uchida, J. Y., and Aragaki, M. 1979. Ceratocystis blight of Syngonium podophyllum. Plant Dis. Rep. 63:1053-1056.

Warshauer, F. R., and Jacobi, J. D. 1982. The distribution and status of Vicia menziesii Spreng. (Leguminosae), Hawaii's first officially listed endangered plant species. Biol. Conserv. 23:111-126.

White, T. J., Bruns, T., Lee, S., and Taylor, J. W. 1990. Amplification and direct sequencing of fungal ribosomal RNA genes for phylogenetics. Pages 315-322 in: PCR Protocols: A Guide to Methods and Applications. D. H. G. M. A. Innis, J. J. Sninsky, and T. J. White, eds. Academic Press, Inc., San Diego, CA.

Wu, C. P., Chen, G. Y., Li, B., Su, H., An, Y. L., Zhen, S. Z., and Ye, J. R. 2011. Rapid and accurate detection of Ceratocystis fagacearum from stained wood and soil by nested and real-time PCR. For. Pathol. 41:15-21.

Yang, A., and Juzwik, J. 2017. Use of nested and real-time PCR for the detection of Ceratocystis fagacearum in the sapwood of diseased oak species in Minnesota. Plant Dis. 101:480-486. 